\title{
The Effect of Broadcast Nitrogen Fertilization Rates and Placement on the Growth of Green Ash Trees
}

\author{
Gary Watson
}

\begin{abstract}
Tree responses to slow-release nitrogen fertilization treatments were limited, but application of fertilizer to the inner half of the root zone improved caliper growth and relative chlorophyll content. Concentrating nitrogen fertilizer applications closer to the base of the tree may be able to take advantage of naturally higher root density, in addition to any further root stimulation resulting from the applied fertilizer treatment. The study site was moderately fertile, as are many urban landscapes where lawn and planting beds surrounding trees are fertilized. The pre-existing level of fertility may have contributed to the limited growth response to the nitrogen applications.

Key Words. Fraxinus pennsylvanica; Growth Response; Nitrogen; Tree Fertilization; Tree Health.
\end{abstract}

Visible nutrient deficiency symptoms are not commonly observed on the majority of trees growing in urban and suburban landscape situations, yet tree fertilization services are routinely offered by arborists. In the absence of the need to correct a visible nutrient deficiency, the reason for fertilizing urban landscape trees must be clear. Rates of nutrients applied should be based on demonstrated need (e.g., deficiency symptom, soil or foliar analysis, clearly defined objective) (Smiley et al. 2002; ANSI 2004). Application methods should maximize nutrient availability to tree roots and minimize losses to the environment.

Arborists commonly justify fertilizer treatments as a substitute for natural nutrient cycling disrupted by the removal of tree litter in landscapes. In an Eastern deciduous hardwood forest, the amount of nitrogen in fallen litter was measured at $0.27-0.46 \mathrm{~kg}$ $\mathrm{N} / 100 \mathrm{~m}^{2} / \mathrm{yr}$ (Wells et al. 1972; Larcher 1975). The amount of nitrogen potentially returned to the soil in the form of tree litter from four landscape tree species was similar or slightly higher at $0.48-0.72 \mathrm{~kg} \mathrm{~N} / 100 \mathrm{~m}^{2} / \mathrm{yr}$ (Werner 2000). The recommended annual rates for landscape tree fertilization of $0.96-2.88 \mathrm{~kg}$ $\mathrm{N} / 100 \mathrm{~m}^{2} / \mathrm{yr}$ (Smiley et al. 2002; ANSI 2004) are up to 10.6 times greater than the amount that could be lost through litter removal.

Lawn fertilization alone may exceed replenishment of nutrients lost by removal of litter. Fertilization program recommendations for improved varieties of bluegrass are $0.96-1.92 \mathrm{~kg} \mathrm{~N} / 100 \mathrm{~m}^{2} / \mathrm{yr}$ (Scotts Miracle-Grow Company; Voight et al. website). In a survey of lawn care practices, homeowners reported actual annual application of $0.24-1.51 \mathrm{~kg} \mathrm{~N} / 100 \mathrm{~m}^{2} / \mathrm{yr}$ (Osmond and Hardy 2004).

Arborists often contend that broadcast applications of lawn fertilizer are ineffective for trees (Lanphear 2000; ANSI 2004), presumably because the nutrients are taken up by the grass before reaching tree roots. While tree root densities can be reduced in the uppermost soil layers where competition with grass roots is most intense, they are not completely eliminated (Watson 1988; Green and Watson 1989). Trees should have some access to nutrients in the upper soil layers though grass roots may dominate.
Shade from trees can also weaken the turfgrass beneath it, reducing root competition. Since irrigation rate, nitrogen source and rate, grass species and vigor, season, and soil type can all influence nitrogen leaching rates in turfgrass systems (Petrovic 1990) amounts of nitrogen leached can vary widely from less than $1 \%$ to $71 \%$ of that applied (Petrovic 1990; Guillard and Kopp 2004; Barton and Colmer 2005; Paré et al. 2006; Mangiafico 2007). The amount of nitrogen leached through the soil profile was similar in a forest and unfertilized lawn system at $1.4 \mathrm{~kg} / \mathrm{ha}$, compared to $6.0 \mathrm{~kg} / \mathrm{ha}$ in fertilized lawns (Gold et al. 1990). This evidence suggests nitrogen applied to lawns is available to tree roots.

Tree age and size must also be considered when determining nitrogen fertilizer rates. On younger trees, with adequate space to expand above and below ground, the goal of fertilization is often rapid growth. For trees that have not yet reached their mature size, Smiley et al. (2002) recommends $0.96-1.92 \mathrm{~kg} \mathrm{~N} / 100 \mathrm{~m}^{2} / \mathrm{yr}$, not to exceed $2.88 \mathrm{~kg} \mathrm{~N} / 100 \mathrm{~m}^{2} / \mathrm{yr}$ if rapid growth is the primary objective. Rates of nitrogen fertilization reported for field production of woody plants are similar, typically $1.30-1.85 \mathrm{~kg} \mathrm{~N} / 100 \mathrm{~m}^{2} / \mathrm{yr}$ (Cripps 1992; Juntunen and Rikala 2001; Cregg et al. 2004), with one report as high as $2.8 \mathrm{~kg} \mathrm{~N} / 100 \mathrm{~m}^{2} / \mathrm{yr}$ (Ingram et al. 1998).

For older trees, maintenance of moderate vigor and growth rates and a favorable root-crown balance are desirable. For mature trees, Smiley et al. (2002) recommend maintenance rates of $0.96-1.44 \mathrm{~kg} \mathrm{~N} / 100 \mathrm{~m}^{2}$ but allows up to a maximum rate of $2.88 \mathrm{~kg} \mathrm{~N} / 100 \mathrm{~m}^{2}$. These rates are very similar to the rates used to promote rapid growth of nursery stock. They exceed nutrients lost through litter removal and may not be appropriate for mature trees when rapid growth is not the goal.

Tree fertilization standards and best management practices specify that fertilizer should be applied evenly from near the trunk to near the dripline (Smiley et al. 2002; ANSI 2004). Greater root proliferation near the base of the trunk has been previously reported for trees growing in turf (Watson 1996). In areas of soil with high nitrogen levels, roots proliferate and absorption per 
unit of root is also increased (Chamuah 1988; Watson 1994; review papers by Robinson 1994 and Hodge 2004). Applying fertilizer in a smaller area nearer the trunk, thereby increasing the rate per unit area of soil, could take advantage of these root stimulating and absorption efficiency effects, thereby increasing uptake.

Reports on the effectiveness of different application methods vary. In the field, there was no reduction in pecan [Carya illinoensis (Wangenh) C. Koch] yield when nitrogen rates were cut in half and applied to a limited area by drip irrigation rather than by broadcasting (Whorley 1995). Several studies have reported no difference between broadcast application, drill holes filled with granules, and liquid injection applications (Neely et al. 1970; Funk 2000), or only a slightly greater growth response from holes filled with granules (Smith 2000).

This study utilized young trees, growing on a soil where a quick release nitrogen formulation had proven effective in stimulating growth of similar trees in the past (Neely et al. 1970). The objective of this study was to measure tree growth responses in relation to placement and rate of a slow release nitrogen fertilizer application to determine if fertilizers can be applied more effectively, or if rates could be reduced.

\section{METHODS}

A site with 'Summit' green ash (Fraxinus pennsylvanica 'Summit'), $15 \mathrm{~cm}$ average caliper, growing in established turf at $4.8 \mathrm{~m}$ spacing on Ozaukee silt loam soil was used for this study (National Resource Conservation Service). Trees exhibited typical growth and color for their species and age. The turf was mowed only two or three times each growing season. No supplemental irrigation was provided.

The degree of overlap of root systems of adjacent trees was investigated prior to initiation of fertilization treatments. To avoid disturbance to the experimental trees, trenches were dug at the midpoint between similar trees on the site with the same spacing $(2.4 \mathrm{~m}$ from each tree). This midpoint was typically less than $30 \mathrm{~cm}$ beyond the dripline. The trenches exposed very few tree roots over $6 \mathrm{~mm}$ diameter. Overlap of root systems was not considered a problem.
The maximum fertilization area for each tree was a $4.8 \mathrm{~m}$ diameter square $\left(23 \mathrm{~m}^{2}\right)$. This area was slightly wider than the dripline, which is commonly designated as the soil surface area where fertilizer should be applied (Smiley et al. 2002). Fertilizer was applied to all or a portion of this area: the entire square, the inner half of the total soil surface area $(3.4 \mathrm{~m}$ diameter square area), or the outer half of the total soil surface area (the outer $0.7 \mathrm{~m}$ of the $4.8 \mathrm{~m}$ diameter square area).

The trees were fertilized with Nu-Gro Nitroform ${ }^{\circledR}$ granular 380-0 fertilizer, a urea formaldehyde nitrogen source with $71 \%$ of the nitrogen from a water-insoluble fraction. Annual application rate variations were based on $1.92 \mathrm{~kg} \mathrm{~N} / 100 \mathrm{~m}^{2}$ over the maximum 23 $\mathrm{m}^{2}$ application area, or $0.44 \mathrm{~kg} \mathrm{~N} /$ tree. When only half of the area was fertilized, either the entire amount was applied to maintain a consistent amount per tree, or the amount was cut in half to maintain a consistent rate per unit of soil surface area. See Table 1 for a complete listing of treatment combinations. The $1.92 \mathrm{~kg} \mathrm{~N} / 100$ $\mathrm{m}^{2}$ rate was chosen because it is the mid-point of the standard tree fertilization rates used by arborists (ANSI 2004). There were five replications of each fertilizer treatment, applied annually for three years on May 16, 2002; May 29, 2003; and May 11, 2004.

Late in each growing season, when annual growth was complete and terminal buds were set, terminal twig growth was measured on two vigorous, nonapical branches just above the center of the crown, on opposite sides of the tree. The final year, when trees were destructively harvested, there was an opportunity to sample more extensively throughout the crown. Ten branches from each tree were measured. Two undamaged fully-expanded leaves from the same branches were used to measure leaf area on a Delta-T (video) Area Meter. Relative chlorophyll content was measured on each of the leaves with a Minolta SPAD-502 meter. Caliper was measured annually at $30 \mathrm{~cm}$ above grade. Since caliper was not measured, the season prior to initiation of treatments, increase for the first year could not be calculated.

One-way ANOVA $(P \leq 0.05$, Normality, $P>0.05)$ with separation of means by the Holm-Sidak Method (SigmaStat 3.0, SPSS Science) was used to compare caliper increase, twig growth, leaf area, and SPAD measurements from each year.

Table 1. Growth responses of green ash trees to three different placements of fertilizer and two rates.

\begin{tabular}{|c|c|c|c|c|c|c|}
\hline & \multicolumn{3}{|c|}{ Caliper increase (cm) } & \multicolumn{3}{|c|}{ Twig growth (cm) } \\
\hline & & 2003 & $2004^{y}$ & 2002 & 2003 & 2004 \\
\hline Entire root zone-full rate ${ }^{z}$ & & 1.9 & $1.2 \mathrm{~b}$ & 41.9 & 63.7 & 15.5 \\
\hline Inner area-full rate & & 1.3 & $2.9 \mathrm{a}$ & 39.8 & 73.9 & 14.0 \\
\hline Inner area-half rate & & 1.0 & $1.4 \mathrm{~b}$ & 34.8 & 61.0 & 14.0 \\
\hline Outer area-full rate & & 1.2 & $1.0 \mathrm{~b}$ & 38.7 & 74.3 & 17.0 \\
\hline Outer area-half rate & & 0.9 & $0.9 \mathrm{~b}$ & 46.2 & 60.9 & 14.6 \\
\hline Control & & 1.1 & $1.4 \mathrm{~b}$ & 50.3 & 64.8 & 13.3 \\
\hline \multirow[t]{3}{*}{$\mathrm{P}$ value } & & 0.18 & 0.03 & 0.84 & 0.39 & 0.88 \\
\hline & & SPAD & & \multicolumn{3}{|c|}{ Leaf Area $\left(\mathrm{cm}^{2}\right)$} \\
\hline & 2002 & 2003 & $2004^{x}$ & 2002 & 2003 & 2004 \\
\hline Entire root zone, full rate & 48.36 & 47.82 & 37.99de & 72.5 & 100.9 & 102.5 \\
\hline Inner area-full rate & 48.68 & 50.20 & $42.12 \mathrm{ae}$ & 61.6 & 110.7 & 122.2 \\
\hline Inner area-half rate & 49.40 & 44.50 & 40.72ace & 82.5 & 101.8 & 160.3 \\
\hline Outer area-full rate & 49.96 & 47.28 & 40.16de & 58.6 & 102.8 & 126.2 \\
\hline Outer area-half rate & 46.60 & 43.60 & $37.69 \mathrm{~cd}$ & 85.1 & 94.4 & 146.7 \\
\hline Control & 47.42 & 47.46 & $36.26 \mathrm{bd}$ & 77.7 & 98.7 & 105.0 \\
\hline$P$ value & 0.68 & 0.60 & 0.08 & 0.32 & 0.72 & 0.27 \\
\hline
\end{tabular}

${ }^{\mathrm{z}}$ Entire root zone $=4.8 \mathrm{~m}$ diameter square, full rate $=1.92 \mathrm{~kg} \mathrm{~N} / 100 \mathrm{~m}^{2}$, or $0.44 \mathrm{~kg} \mathrm{~N} /$ tree. Square footage or fertilizer amount was halved for other treatments. There were five replications of each treatment.

${ }^{y}$ Values followed by the same letter are not significantly different at $P \leq 0.05$

${ }^{x}$ Values followed by the same letter are not significantly different at $P \leq 0.10$ 


\section{RESULTS \& DISCUSSION}

Significant tree responses to the fertilization treatments were limited (Table 1). In the third year only, caliper increase of the inner area-full rate treatment was greater than all other treatments. Twig growth and leaf area were not increased by any treatment combination in any year. Even the more thorough sampling in the third year did not reveal differences among treatments, though it did produce lower and likely more representative, average twig growth measurements for all treatments, compared to previous years. In the third year, SPAD measurements of the inner area-full rate and the inner area-half rate treatments were marginally significantly $(\mathrm{P}=$ $0.086)$ greater than the control. The trees were also visibly greener.

Nutrient uptake nearer the tree may have been enhanced by greater natural fine root development (Watson 1996). Concentration of nutrients can increase root proliferation and uptake (Robinson 1994; Hodge 2004). It may be that concentrating the nitrogen fertilizer applications closer to the base of the tree can take advantage of the naturally higher fine root density, in addition to any further fine root stimulation resulting directly from the nitrogen application. Future research should include monitoring changes in fine root development accompanying aboveground responses to placement and rate of fertilizer application.

The lack of any response to the treatments until the third year was not expected, but could possibly be explained by the annual growth cycle of this temperate deciduous species and the nature of the fertilizer product. Since $71 \%$ of the nitrogen was in a slowrelease formulation, and application was in May, annual twig growth may have been completed by the time sufficient nitrogen was released, absorbed, and transported to the shoots, preventing a growth response in the first year. If the slow-release formulation was also ineffective in increasing bud size in the first year, twig growth increase in the second year may have still been limited, though an increase in SPAD readings could have been expected. The third year could have been the first growing season when fertilizer was present to affect both bud formation in the previous season and current season growth. If increased uptake was dependent on an increase of fine root density in response to the more concentrated fertilizer, it may have taken time to develop.

Another possible factor in the limited growth response from the fertilizer treatments could be related to moderate level of natural fertility on the site. Similar Ozaukee soils in the region average $4.3 \%$ carbon, $0.34 \%$ nitrogen, $12.65 \mathrm{C} / \mathrm{N}$ (Bryant Scharenbroch, The Morton Arboretum, pers. comm.). The limited overall response to fertilization application raises questions as to how much fertilization is appropriate for trees in well-maintained urban landscapes where fertilizers are applied to lawns and other plantings. Further studies on different species, application rates, and patterns are needed on more urban, less fertile sites. A broader approach to providing a healthy soil environment (physical and biological, as well as chemical) may also be needed in comprehensive plant health care programs.

Fertilizer recommendations are currently based on soil surface area. Basic geometry calculations show the inner half of the total soil area within the dripline extends $70 \%$ of the radius to the dripline. This was the inner area used in this study, but may actually be similar to the way fertilizer is often applied in practice, depending on the soil surface accessible, or how "from the trunk to near the dripline" (Smiley et al 2002), is interpreted. If anything, the results of this study may reinforce the recommendation to not apply fer- tilizer beyond the dripline (Smiley et al 2002). The results of this study should not be interpreted as a mandate for basal application of fertilizer, as has become standard for some insecticides and growth regulators. Further research on less fertile sites could provide more information on how to apply fertilizers more effectively.

Acknowledgments. This study was funded, in part, by a grant from The Care of Trees, Wheeling, Illinois.

\section{LITERATURE CITED}

American National Standard Institute. 2004. American National Standard for Tree Care Operations - Tree, Shrub, and Other Woody Plant Maintenance - Standard Practices (Fertilization) (A300, Part 2). Tree Care Industry Association, Manchester, New Hampshire.

Barton, L., and T.D. Colmer. 2005. Irrigation and fertilizer strategies for minimizing nitrogen leaching from turfgrass. Agricultural Water Management 80:160-175.

Chamuah, G.S. 1988. The effect of nitrogen on root growth and nutrient uptake of young tea plants (Camellia sinensis L.) grown in sand culture. Fertilizer Research 16:59-65.

Cregg, B., C. Rios, J. Hart, and D. Briggs. 2004. Fate of nitrates in field nursery production systems. USDA Forest Service Proceedings RMRS-P-33. 50-54.

Cripps, R.W. 1992. N fertilization of field grown woody Ornamentals. Proceeds of the SNA Research Conference 37:128-132.

Funk, R.C. 2000. The effect of fertilizer source and placement on tree growth. pp. 83-86. In Siewert, A, A. Siewert, B. Rao, and D. Marion (eds). Tree and Shrub Fertilization: Proceedings from an International Conference on Tree and Shrub Fertilization. May 17-18, 2000, Fairlawn, Ohio.

Gold, A.J., W.R. DeRagoon, W.M. Sullivan, and J.L. Lemunyon. 1990. Nitrate-nitrogen losses to groundwater from rural and suburban land uses. Journal of Soil \& Water Conservation 45:305-310.

Green, T., and G.W. Watson. 1989. The Effect of Organic Surface Mulch on the Establishment of Bare Root Trees. Journal of Arboriculture 15:268-272.

Guillard, K., and K.L. Kopp. 2004. Nitrogen fertilizer form and associated nitrate leaching from cool-season lawn turf. Journal of Environmental Quality 33:1822-1827.

Hodge, A. 2004. The plastic plant: root responses to heterogeneous supplies of nutrients. New Phytologist 162:9-24.

Ingram, D.L., B. Roach, and M. Klahr. 1998. Effects of controlled-release fertilizers on growth and nutrient content of field-grown nursery crops. Proceeds of the SNA Research Conference 43:124-127.

Juntunen, M-L, and R. Rikala. 2001. Fertilization practice in Finnish forest nurseries from the standpoint of environmental impact. New Forests 21:141-158.

Lanphear, L. 2000. Tree Fertilization: An Arborist's Perspective. pp 143-150. In: A Siewert, A. Siewert, B. Rao, and D. Marion (eds). Tree and Shrub Fertilization: Proceedings from an International Conference on Tree and Shrub Fertilization. May 17-18, 2000, Fairlawn, Ohio.

Larcher, W. 1975. Physiological Plant Ecology. Springer-Verlag, Berlin and New York.

Mangiafico, S.S., and K. Guillard. 2007. Nitrate leaching from Kentucky bluegrass soil columns predicted with anion exchange membranes. Soil Science Society of America Journal 71:219-224.

National Resource Conservation Service Web Soil Survey <http://websoilsurvey.nrcs.usda.gov/app/WebSoilSurvey.aspx> 
Neely, D., E.B. Himelick, and W.R. Crowley, Jr. 1970. Fertilization of established trees: A report of field studies. Illinois Natural History Survey bulletin 30(4):235-266.

Osmond, D.L., and D.H. Hardy. 2004. Characterization of turf practices in five North Carolina Communities. Journal of Environmental Quality 33:565-575.

Paré, K., M.H. Chantigny, K. Carey, W.J. Johnston, and J. Dionne. 2006. Nitrogen uptake and leaching under annual bluegrass ecotypes and bentgrass species: A lysimeter experiment. Crop Science 46:847-853.

Petrovic, A.M. 1990. The fate of nitrogenous fertilizer applied to turfgrass. Journal of Environmental Quality 19:11-14.

Robinson, D. 1994. The responses of plants to non-uniform supplies of nutrients. New Phytologist 127:635-674.

Scotts Miracle-Grow Company. Annual lawn care program builder. $<$ http://www.scotts.com>

Smiley, E.T, S.J. Lilly, and P. Kelsey. 2002. Best Management Practices: Tree and shrub fertilization. International Society of Arboriculture, Champaign, Illinois.

Smith, Elton. 2000. Tree growth as influenced by fertilizer placement. pp. 79-82. In: A. Siewert, A. Siewert, B. Rao, and D. Marion (eds). Tree and Shrub Fertilization: Proceedings from an International Conference on Tree and Shrub Fertilization. May 17-18, 2000, Fairlawn, Ohio.

Voigt, T, T. Fermanian, and D. Wehner. Turfgrass fertilization. <http:// www.turf.edu/extension/est-fert.html>

Watson, G.W. 1988. Organic Surface Mulch and Grass Competition Influence Root Development. Journal of Arboriculture 14:200-203.

Watson, G.W. 1994. Root Growth Response to Fertilizers. Journal of Arboriculture 20:4-8

Watson, G.W. 1996. Tree Root System Enhancement with Paclobutrazol. Journal of Arboriculture 22:211-217.

Wells, C.A., D. Whigham, and H. Lieuth. 1972. Investigation of mineral nutrient cycling in an upland piedmont forest. Journal of the Elisha Mitchell Scientific Society 88:66-78.

Werner, L.W. 2000. Nitrogen relations of ornamental trees in urban soils: a first look. Master's Thesis. University of Wisconsin - Stevens Point, Stevens Point, WI 54481. 99 pp.

Worley, R.E., J.W. Daniel, J.D. Dutcher, K.A. Harrison, and B.G. Mullinix. 1995. A long-term comparison of broadcasts application versus drip fertigation of nitrogen for mature pecan trees. HortTechnology 5:43-47.

Gary W. Watson

The Morton Arboretum

4100 Illinois Route 53

Lisle, IL 60532

gwatson@mortonarb.org
Résumé. La réponse des arbres à des traitements de fertilisation azotée au moyen d'engrais à libération lente était limitée, mais l'application d'engrais à l'intérieur de la demi-zone du développement racinaire a produit une augmentation de la croissance en regard du calibre ainsi que du contenu relatif en chlorophylle. La concentration des applications d'engrais en azote près de la base des arbres pourrait permettre de prendre avantage de la densité naturelle plus élevée en racines, et ce en surplus de toute autre stimulation des racines résultant d'une application d'engrais. Le site d'étude était modérément fertile, tout comme de nombreux aménagements urbains où les pelouses et les lits de plantation qui entourent les arbres sont fertilisés. Le niveau préexistant de fertilité pourrait avoir contribué à la réponse limitée de croissance aux applications d'azote.

Zusammenfassung. Die Reaktion von Bäumen auf einen langsam wirkenden Stickstoffdünger war begrenzt, aber die Applikation von Dünger in die innere Hälfte der Wurzelzone verbesserte das Dickenwachstum und den relativen Chlorphyllgehalt. Wenn die Stickstoffdüngergaben mehr an die Stammbasis konzentriert werden, könnte das zu einer höheren Wurzeldichte, zusätzlich zu gefördertem Wurzelwachstrum durch die Stimulation aus dem applizierten Dünger führen. Der Standort der Feldstudie war relative fruchtbar, so wie viele urbane Böden, wo die Wiesen Beete um die Bäume entsprechend gedüngt werden. Die vor der Studie existierden Nährstoffgehalte könnten zu der limitierten Reaktion auf die Stickstoffapplikationen geführt haben.

Resumen. Las respuestas de los árboles a tratamientos de fertilización con nitrógeno de lenta liberación fueron limitadas, pero la aplicación de fertilizante a la mitad interna de la zona de raíces mejoró el crecimiento del calibre y el contenido relativo de clorofila. Las aplicaciones de fertilizantes concentrados de nitrógeno cerca de la base del árbol puede ser capaz de tomar ventaja de la alta densidad de raíces, además de cualquier estimulación resultante de la aplicación del fertilizante. El sitio de estudio fue moderadamente fértil, en la medida que muchos paisajes urbanos donde el pasto y las camas de plantación de árboles son fertilizados. Los niveles pre-existentes de fertilidad pueden haber contribuido a la respuesta en crecimiento a las aplicaciones de nitrógeno. 